\title{
Motivational Factors for Visual Deficient Users
}

\author{
Angélica Fonseca da Silva Dias \\ Universidade Federal do Rio de Janeiro, Núcleo de Computação Eletrônica, \\ Rio de Janeiro, Brasil, Caixa Postal 2324, CEP 20001-970, \\ angelica@nce.ufri.br \\ and \\ Mônica Ferreira da Silva \\ Universidade Federal do Rio de Janeiro, Núcleo de Computação Eletrônica \\ Rio de Janeiro, Brasil, Caixa Postal 2324, CEP 20001-970, \\ monica@nce.ufri.br \\ and \\ Eber Schmitz \\ Universidade Federal do Rio de Janeiro, Núcleo de Computação Eletrônica \\ Rio de Janeiro, Brasil, Caixa Postal 2324, CEP 20001-970, \\ eber@nce.ufrj.br \\ and \\ Donaldo de Souza Dias \\ Universidade Federal do Rio de Janeiro, COPPEAD \\ Rio de Janeiro, Brasil, Caixa Postal 68514, CEP 21941-972, \\ donaldo@coppead.ufri.br
}

\begin{abstract}
:
This research aims to investigate the adoption of technology by the visual deficient. The technology studied was the Dosvox software, a support tool for the visual deficient produced at NCE/UFRJ. A qualitative method, through a case study, was used to address professional and social expectation and the perception of visual deficiency bearers as to the intrinsic motivational factors (ease-of-use and social pressure) as well as to the extrinsic motivational factor (perceived usefulness). The motivational factors used have been extracted from the TAM (Technology Acceptance Model) and based on that model a standard form was used to gather information. Ten visual deficiency bearers, users of Dosvox, have been interviewed. The interviewees have been unanimous in affirming that, for those who are learning, Dosvox is the easiest software to use, stimulating them to return to studies and to social life. A significant group has confirmed that after their training with Dosvox, they have become more competitive as to the work market. It has also been observed a stronger influence of the perceived usefulness factor over the social pressure and the perceived ease-of-use. The results of this research may indicate new approaches to the development of specific information systems for the visual deficient.
\end{abstract}

Keywords: Motivational Factors, Technology Adoption, Visual Deficiency Bearers, TAM. 


\section{Introduction}

Several studies have been carried out aiming at identifying both intrinsic ${ }^{1}$ and extrinsic ${ }^{2}$ factors involved in the decisions, intentions and satisfaction of individuals as to the acceptance and use of Information Technology. Most of these studies are based on the TAM - Technology Acceptance Model, devised by Davis [4]. That model proposes that two variables - the perceived usefulness and the perceived ease-of-use - directly influence in the attitude and intention of using technology.

The present research has aimed at verifying how the motivational factors perceived usefulness, perceived ease-of-use and social pressure have influenced the intention of using a software tool for the visual deficient in Brazil, specifically in Rio de Janeiro, and how they deal with information technology, more specifically with the Dosvox ${ }^{3}$, in their professional and social lives. Information Technology provides resources which allow the visual deficient to have better conditions as to the access to education, consequently allowing an improve of their quality of life, either through intellectual (access to information and education), personal (the possibility of communicating with other individuals on equal grounds, and entertaining) and professional growth (having adequate means to the develop a professional activity leading to the achievement of their finance independence) [2].

The relevance of the present research lies in:

- Amplifying the knowledge on the interaction between the visual deficient and technology, specially in the social setting.

- Studying a special public whose work market is being conquered with dedication and the development of technological tools.

- Extending the studies on the TAM, reinforcing its theoretical and empirical validity, and deepening it to visual deficient users.

- Investigating and suggesting actions to increase the acceptance and the use of technology by visual deficiency bearers, aiming at knowing better both the limits and the opportunities technology might offer as to personal and professional use on the part of these users.

- Analyzing the human component of information technology, not only as the part of it which receives the impact of technology, but also and mainly, as an active agent, and one essential to the success of that technology. [22]

The results of this research may contribute to significant changes in present and future tools, including the ones used in companies, to receive these new professionals. This research also contributes to making one reflect over specific aspects of the Brazilian reality.

As follows, we are going to define the visual deficient; discuss the TAM in its parcimonious version and exploit some empirical researches, specially the ones applied in Brazil, which verify the adoption of technology through that model; present the method used on that investigation, emphasizing the profile of the interviewees; discuss the results obtained; and make considerations over new research in the area.

\section{Visual Deficiency Bearers}

This century brings to visual deficiency bearers a successive breaking of milenar obstacles such as exclusion and segregation, where these individuals were abandoned to their own fate or isolated in specialized institutions. The main key for this evolution is technology, to be applied to overcome anatomic-psychological obstacles. [19]

The subjects of this research, the Dosvox software users, are visual deficient, that is, people with some visual problem unable to see or to see well - limited or impaired as to access to: orientation and independent mobility; interaction with the environment; concept acquisition; acquisition of manual skills and access to print word. [16]

According to Borges [2], most of the visual deficient in Brazil is semi-illiterate people or those with elementary education, and with extremely difficult access to it. Such individuals need special education, adequate to their needs, and specific technology. In accordance to this believe, Naumann [15] proposed a methodological approach to teach CISCO $^{\circledR}$ to deficient students - either visual or motor deficient: Habilitar. Naumann studied more than ten students and showed that Habilitar enabled these individuals to access information that otherwise would be impossible for them, and enhanced the quality of life of those people by offering new opportunities of work and socialization, both supported by technology.

${ }^{1}$ Intrinsic factors: motivation derives from the activity itself [7]

${ }^{2}$ Extrinsic factors: motivation derives from that which is obtained through participating in the activity. [7]

3 Software designed to visual deficiency bearers, which converts microcomputer-generated textual information into sound. [2] 
Some researches have been carried out to better understand the need of that segment. This work investigates, for instance, the adoption of technology by visual deficiency bearers based on the TAM, which will be depicted as follows.

\section{TAM - Technology Acceptance Model}

Several studies investigate the behavior of a user as to Information Technology. The Technology Acceptance Model has been vastly used by researchers with the objective of better understanding the factors that involve the adoption and use of technology. Such model has been arisen from studies in the area of "Theory of Reasoned Action"(TRA), which tries to predict the behavior of an individual based on their beliefs and intentions. Fishbein and Ajzen [10] created a model based on TRA named, in this research, Fishbein and Ajzen model.

TAM has been proposed by Davis [4] from the Fishbein and Ajzen model [10] that describes human behavior as dependent on behavior intention, which, on its turn, would be affected by an attitude component (beliefs/perception of consequences which would interfere in the attitude) and by a normative component (how the social context affects intention):

B $\sim$ BI $=$ w1.A + w2.SN, being:

$\mathrm{B}=$ behavior

$\mathrm{BI}=$ behavior intention

$\mathrm{A}=$ attitude - attitude component as to behavior

$\mathrm{SN}=$ subjective norm - normative component as to behavior

$\mathrm{W} 1$ and $\mathrm{w} 2=$ weights referring to each component

Davis [4] has despised the normative component of the Fishbein and Ajzen model, and has proposed two constructs to represent the perceptions that influence the use of an information system. Thus, in the model proposed by Davis, the attitude component is formed based on two variables:

- PU (perceived usefulness) - the level to which an individual believes that using a given system would benefit his performance at work.

- PEOU (perceived ease-of-use) - the level to which an individual believes that using a given system does not require mental or physical effort.

Fishbein and Ajzen [10] have suggested in their work that the representative constructs of the attitude component be generated from the elaboration of a qualitative research focusing on the object being studied. Various researches on the use of systems have already been carried out in the area of Management Information Systems. In so being, Davis [4,5] has been able to raise the two constructs presented above based on a review of the literature.

The first version of Davis ' model (TAM - see figure 1) has been described by him as a parcimonious one, since it presents only the central variables, which influence the intention of use. However, the reality depicted by the model is much more complex and involves several factors which affect, directly or indirectly, the acceptance on the part of the user. Venkatesh and Davis [25], for instance, investigate that the perceived usefulness can be affected by subjective norms, the task relevance and the results showed, whereas Venkatesh [24] vinculates the ease-of-use perception to computer self-efficiency, external control perception (external control focus) and computer anxiety. Some of these constructs have already been noticed by Fishbein and Ajzen [10], as previously seen.

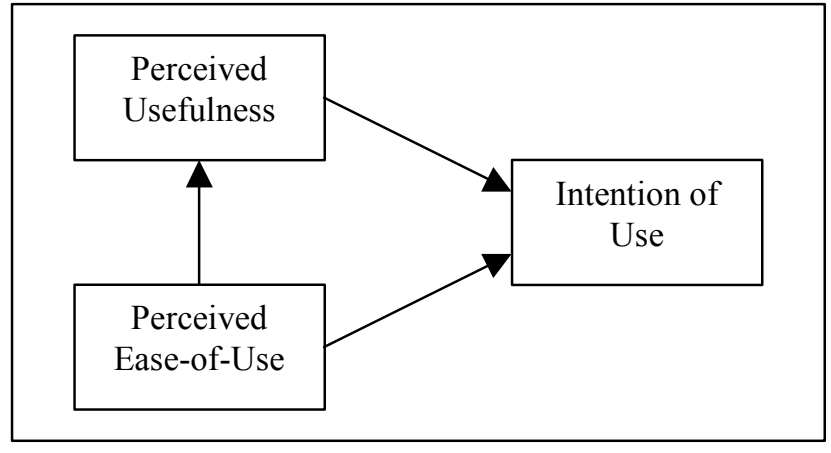

Figure 1: TAM - Technology Acceptance Model

Several researches have been trying to validate the TAM and perceived the existence of previous variables, which alter the model premises in some way. As follows we cite some of these researches. 


\subsection{Empirical Studies using the TAM}

Dias [7], using some elements of TAM, carried out a research on motivation and use of microcomputers using Brazilian respondents (Figure 2). 79 professionals holding managerial positions, in 55 companies in Rio de Janeiro, have answered a questionnaire. That organizational context will be different in small companies and large corporations: $23 \%$ were multinational companies, $58 \%$ were private companies with Brazilian capital, and $19 \%$ were government ones. The research was based on the psychoanalytical presupposition that the intrinsic motivational factors would have precedence over the extrinsic ones. However, the results have once more indicated usefulness - an extrinsic factor - as the major motivator to the use of technology.

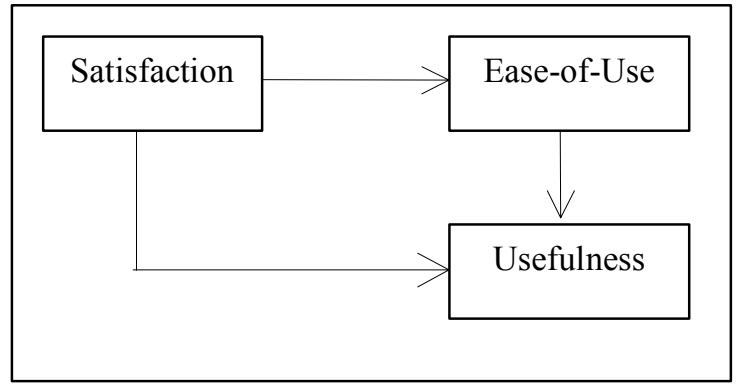

Figure 2: Dias Model [7]

The existence of a positive correlation between the perceived satisfaction and the perceived ease-of-use has been confirmed, that is, the greater the satisfaction in using computers is, the higher the perceived ease-of-use in using them. Moreover, both the perceived satisfaction and the perceived ease-of-use have a positive influence on the perceived usefulness. It has also been verified that the perception that computers are easy to use may reduce anxiety in relation to their use.

Venkatesh, Morris and Ackerman [26] have presented a longitudinal research of different genders in the use of technology applied to work, using the Behavior and Planning Theory - BPT. The behavior has been tested for five months, with 355 professionals making use of a new technology. The men have been more strongly influenced to adopt technology by the perception of its usefulness, whereas the women have been more strongly influenced by the subjective norms ${ }^{4}$ and by the perceived behavior control ${ }^{5}$.

In Dias [8], the author adds other variables previous to the model: different age groups and with different education levels are studied. In this sample, it is perceived that satisfaction is given more importance by people with an elementary level of education, being 11 years old in average.

Another research has been later carried out by Dias [8], applying the same three-motivational-factor model to three classes of users in Rio de Janeiro:

- 53 students of an Executive MBA course (lato sensu post-graduation) at a reputable public university, being 36 years of age in average, with 11 years of professional experience; $83 \%$ held a managerial position in 43 companies of different sizes.

- 46 Business undergraduate students of a private university, 22 years of age in average, some of them already were working part-time during the course.

- 39 Elementary School students, $82 \%$ of them in private schools and the other in public ones.

The results have shown that individuals with different education levels demonstrate different perceptions as to the factors which have motivated the use of microcomputers. Elementary School students are more pleased by the use of computers than the other. The MBA students have reported the lowest level of satisfaction.

The usefulness attribute is more perceived by undergraduate students and Elementary School students are the ones who perceived it less.

Finally, the ease-of -use perception is stronger with undergraduate students. Those of the MBA are the ones who less perceive it. Satisfaction would be a self-motivation factor, whereas usefulness seems to be related to a feeling of

4 Subjective Norms refer to the perception of an individual that a great number of people, important to them, think he should or should not execute the behavior referred to. [10]

5 The perceived behavior control is associated to the control over personal and external factors, which may ease or confirm the execution of the behavior. [26]. 
obligation. Dias concludes that information systems will become more attractive to adult users if they become more friendly, have more up-to-date interfaces, and if they are developed with the participation of the users, besides including an intense training program.

Silva and Dias [21] have carried out a survey with 46 employees of an academic Brazilian institution, which was implementing an IMS (Integrated Management System). Studies that have been previously carried out indicated that the influence of subjective norms decreases as the system is used. However, the authors have verified that, although the system has been used for more than three months, the influence of the subjective norms has still shown proved to be very strong. The study has also confirmed the existence of different dimensions between motivational aspects and the relation among some of the factors mentioned in the literature: Subjective Norms, Perceived Usefulness and Intention of Use.

Chao [3] has investigated how art directors of advertising agencies in Rio de Janeiro deal with the technology offered by microcomputers in the work setting. 13 art directors who work or have worked in advertising agencies in Rio de Janeiro have been interviewed. It has been observed that the extrinsic motivational factors prevail over the extrinsic ones, with a higher emphasis on the work setting pressure to the use of microcomputers. Besides that, the results suggest that the most experienced art directors are also the oldest ones and have more difficulty in using computers.

Dias et al. [9] have applied a survey having as the object of study a software for visual and motor deficiency bearers. The sample was composed of seven users (four users of the Dosvox and three of the Motrix ${ }^{6}$ ). The sample was composed of men 35 years old in average, ranging from 23 to 43, with different education backgrounds, and at least two years of experience using the researched software: Dosvox and Motrix.

The perception of the users as to the ease-of-use, usefulness and intention of use of the software have been analyzed. Such perception refers to the intrinsic motivational factor (ease-of-use) and the extrinsic motivational factor (perceived usefulness) extracted from Davis's Technology Acceptance Model [4,5]. This research is also based on studies carried out by Dias [8].

The result analysis has allowed the development of suggestive considerations over the motivational factors for the use of computer tools by physical deficiency bearers. The extrinsic motivational factor (perceived usefulness) and the extrinsic motivational factor (ease-of-use) have obtained high values for the Dosvox. Besides that, it has been observed that Dosvox users had a better perception as to the usefulness and, consequently, a higher intention of use than Motrix users. The results of this research have shown how computer technology tools are necessary to the physical deficient, for a market demand: not only for personal fulfillment and life objective, as well as for their insertion in the work market. At the same time, it is important to consider the difference between what would be "authentic motivation", generated by factors intrinsic to the individual, and mere conditioning, stimulated by extrinsic variables, therefore creating behaviors which will not remain on their own in case the punishment or the reward associated to them are supressed [1].

Silva [22] has carried out a research with 231 users of eight information systems distributed among eight Brazilian companies, with the aim of identifying the influence of human factors over the intention of use of information systems.

This research has used a more recent version of the TAM, which incorporates social influence. It has been verified that usefulness, followed by the ease-of-use, has proven to be the major direct motivator to the adoption of a technology. Social influence has directly and indirectly influenced the intention of use for its effect over the usefulness and the easeof-use. Thus, the more the user perceives the help offered by the system to their work, its ease-of-use and the incentive as to its use on the part of people they consider important, the more they will intend to use it.

The present research is strongly based on three theoretic perspectives:

- TRA (Theory of Reasoned Action) [10] that suggests that human behavior is determined by an attitude component (perception and individual beliefs) and a norm component (social influences expressed by means of subjective norms).

- Davis's TAM $[4,5]$, which proposes the perceived usefulness as the major motivational factor in the use of computer technology.

- The distinction between extrinsic and intrinsic motivators made by Deci [6] and Igbaria, Parasuraman and Baroudi [11], which indicates that individuals can be motivated to use a computer by intrinsic rewards (satisfaction and entertainment), perceived benefits (usefulness) and external pressure (social pressure).

It is important to point out that we have not identified researches on the adoption of technology by the physical deficient specifically. We present, as follows, the method used in this research highlighting the specific characteristics of the analyzed segment.

${ }^{6}$ A software which enables people with serious motor deficiencies, specially tetraplegy and muscle dystrophy, to have access to microcomputers, thus allowing wide access to writing, reading and communication intermediated by the internet. The system works through voice commands spoken on a microphone. [2] 


\section{Methodology}

This research verifies how visual deficiency bearers from Rio de Janeiro react to the adoption of technology tools, more specifically as to the adoption of the Dosvox software. The present research has aimed at verifying how motivational factors influence the intention of use of a software tool for the visual deficient.

As to the investigation tool used, this research has been carried out from a case study method based on a questionnaire used in previous researches by Davis [4], Venkatesh and Davis [25], and Dias [7]. This study has been applied to the Dosvox tool users with the objective of verifying the relation among the factors raised in the literature.

Ten visual deficiency bearers have been interviewed, nine of which frequented the specialized Benjamin Constant Institute, in Rio de Janeiro, Brazil; and one from Brasilia, where he holds a position in a government institution.

As pointed out by Fishbein and Ajzen [10], for a correct application of his behavior model as to a determined object, it is necessary to specify one sole object. In the case of this research, the software Dosvox, which offers support to the visual deficient, was the object of study.

The interviews have been based on a script with standard questions (see figure 3), composed of objective and multiple choice questions [20]. The aim of that choice was to allow later comparing of answers [14].

The questions were formulated based on a direct approach, in which the real objectives of the research are revealed to the respondents by the very nature of the questions. [13]

A validation of the outline has been made, with two interviewees, allowing us to improve the questions.

The interviews have been recorded in cassette tapes, transcribed and analyzed to the light of the concepts found in the bibliographical review section. Special attention has also been dedicated to the issues addressed by the interviewees, which have generated further considerations as to appropriate technologies for the visual deficient. The answers to the fixed-alternative questions have been submitted to a statistical treatment, which has allowed us to calculate some of the statements presented in the next section.

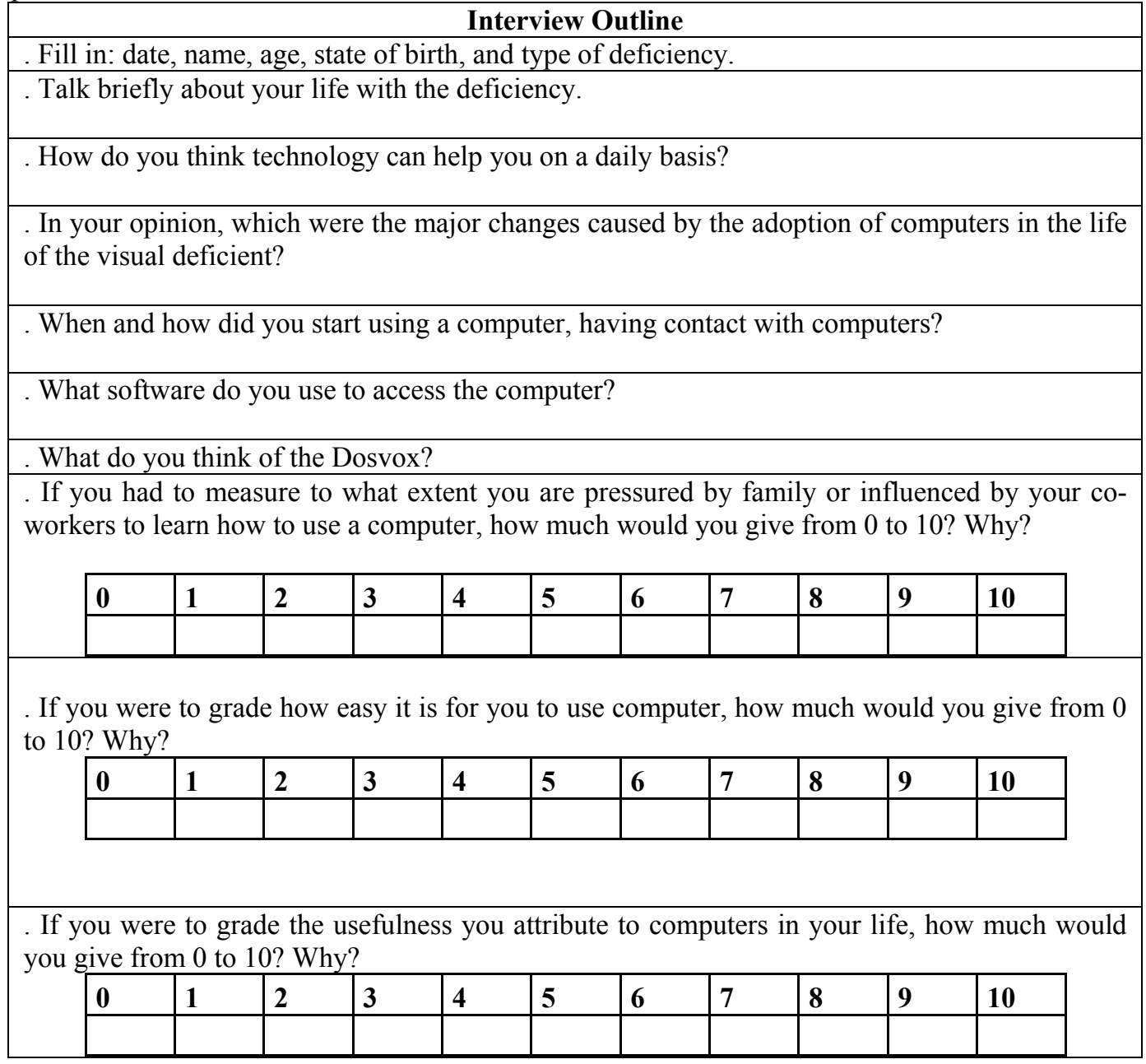

Figure3: Interview Outline 


\section{Obtained Results}

In this section, we focus primarily the descriptive analyses of the respondents and, as follows, the analysis of the motivational factors rose in the questionnaire. Ten visual deficiency bearers have been contacted, making use of a qualitative method of individual interviews. They were five men and five women, with ages ranging from 21 to 56, with different education levels, professional experience and time using a computer, from 2 months to 20 years.

The main changes caused by the introduction of the Dosvox tool, the circumstances in which the respondents have started to use computers, and their personal perceptions of social pressure, ease-of-use and usefulness in relation to that technology have been examined.

Such perceptions refer to intrinsic motivational factors (ease-of-use and social pressure) and to the extrinsic ones (usefulness perceived by the user) taken from the TAM [4,5]. The present research is also based on studies carried out by Dias [7,8] and Dias [9].

Deep alterations, in the lives of visual deficiency bearers, caused by the advent of technology tools, have been verified.

$\begin{array}{lcccccc}\text { Cases } & \begin{array}{l}\text { Social } \\ \text { Pressure }\end{array} & \text { Ease-of-use } & \text { Usefulness } & \text { Age } & \begin{array}{c}\text { Time } \\ \text { Visual } \begin{array}{c}\text { bearing } \\ \text { Deficiency }\end{array}\end{array} & \text { a } \\ \text { A } & 3 & 10 & 8 & 33 & 20 \\ \text { B } & 5 & 5 & 10 & 55 & 4 \\ \text { C } & 10 & 10 & 10 & 49 & 14 \\ \text { D } & 10 & 10 & 10 & 31 & 31 \\ \text { E } & 5 & 9 & 10 & 30 & 2 \\ \text { F } & 10 & 7 & 10 & 21 & 21 \\ \text { G } & 10 & 10 & 10 & 56 & 14 \\ \text { H } & 10 & 10 & 10 & 56 & 3 \\ \text { I } & 10 & 10 & 10 & 49 & 49 \\ \text { J } & 10 & 10 & 10 & 50 & 50 \\ \text { Média } & \mathbf{8 , 3} & \mathbf{9 , 1} & \mathbf{9 , 8} & \mathbf{4 3} & \mathbf{2 1}\end{array}$

Chart 1: Analyzed Constructs

The chart above shows that practically $50 \%$ of the Dosvox users have been using it for more than 20 years. However, $30 \%$ of the users have used other software such as: Virtual Visual [27] and Jaws [12].

The interviewees have been unanimous when affirming that the Dosvox is the easiest software for those who are learning. The advantages mentioned were: its gratuity and the fact that it works in Portuguese (without an accent) as explained by Pimentel [17].

Several users have said that the Dosvox has stimulated them to return to their studies and social life in general.

Some interviewees have pointed out that the tool needs improving, mainly being reviewed, aiming at allowing easier Internet access. An interview has suggested that the commands be made available in $\mathrm{CD}$ to facilitate learning, making the use of a tape recorder in the Dosvox operation classes redundant.

Another flaw pointed out during the interviews was the lack of specialized teachers for this software.

The strong influence of social pressure is perceived in the testimonies made by the visual deficient. Seven out of the ten interviewees have attributed the highest marks to these factors. Some of the interviewees have had more difficulties with family relationships, for they have not found the support they expected, making their social relations more difficult. The other interviewees have achieved more progress in their learning, making technology a part of the family daily life.

Another aspect perceived as an intensifier of social pressure was Brazilian society having a collective feature more than an individual one. According to Chao [3], the use of computers in that sort of society becomes more necessary for it supplies an additional form of communication. That statement has been confirmed in the research, for most of the interviewees have felt strongly influenced by family and by groups of individuals in their communities. They have pointed out the support received to return to their studies, besides the courage to overcome obstacles and prejudice, that is, part of a group and of society again.

Silva and Dias [21] point out that social pressure would come from individuals whose opinions are relevant to their users. That statement has been confirmed by the results of the research, for family support, as to the use of technology, 
and that of friends, as to the facility to get information and acceptance into new communities, have inspired visual deficiency bearers to face new challenges.

The interviewees have assured that the presence of the family is indeed essential to the personal and academic development of the visual deficient, and that friends also contribute so that they persevere in their accomplishments.

Another important point raised during the interviews is that poorly designed sites and systems make the ease-of-use perception more difficult. This analysis does not make reference to the Dosvox, for it is totally projected with communication features coherent to the limitations of the visual deficient [18]. Most of the interviewees have suggested the creation of new technologies, such as the Dosvox, adapted to the needs of the visual deficient.

The ease-of-use factor has presented a 9.1 average, a little higher than social pressure. The interviewees have affirmed that any sort of technology is considered hard to use due to their visual limitations. However, the moment they find technologies adapted to their needs, the ease-of-use barrier is overcome allowing making it possible to consider other issues, such as the perception of usefulness. From that moment on, technology becomes part of their lives.

The perception that the use of a given system improves professional performance [4], has been assured by the results of this research, for most of the interviewees have confirmed that after the training with the Dosvox program, they have become more competitive as to the work market. Visual deficiency bearers believe the Dosvox is the first step towards technology.

\section{Conclusion}

In technology specialized literature, it has also been stated that technology development, associated to some orientation, more and more focused on the user, has been decisive to improve technology tools and increase the users' expectation [23]. The present research confirms that relation - the introduction of technology into the life of deficiency bearers has defined an increase of job opportunities, as well as an increase in the inclusion of these people in society.

The result analysis, supported by statistic calculations applied to the answers given to fixed-alternative questions - even if the sample examined has not been defined with the objective of meeting significance requisites - has allowed the development of suggestive considerations on motivational factors for the use of technology tools in the life of the visual deficient.

The extrinsic motivational factor (usefulness perceived by the user) has prevailed over the intrinsic motivational factors (ease-of-use and social pressure). Besides that, it has been attested that the social setting pressure for the use of computers was an influent factor. Among the visual deficient interviewed, there is a consensus that computers are not mere tools - they are major tools, which allow these individuals to socialize and become professionals.

The skills provided by information technology become more and more vital to these individuals, as far as economic success, political inclusion, and the creation of social nets go. Thus, some ideas to resume this study have come up. It would be interesting to replicate this research into a more significant sample, allowing us to obtain more statistically valid results. Future researches can also deepen the issue of the quality of life of the visual deficient in a setting where the use of technology is mandatory, such as the professional setting.

\section{Bibliographic References}

[1] Bergamini, Cecília W. Motivação: mitos, crenças e mal-entendidos. Revista de Administração de Empresas, São Paulo, v. 30, n. 2, p. 23-34, abr./jun. 1990.

[2] Borges, J. A. Ampliadores de tela de computador: uma visão geral - Revista Técnica do Instituto Benjamin Constant no. 9 - Rio de Janeiro - 1998.

[3] Chao, M.C.Y. Fatores motivacionais para o uso de tecnologia: um estudo junto a diretores de arte de agências de propaganda do Rio de Janeiro - Dissertação de mestrado em Administração - Universidade Federal do Rio de Janeiro COPPEAD, 2004.

[4] Davis, Fred D. A technology acceptance model for empirically testing new end user information systems: theory and results, tese de doutorado, MIT, Boston, MA, 1986.

[5] Davis, Fred D. Perceived usefulness, perceived ease of use and user acceptance of computer technology, MIS Quarterly, vol. 13, n. 3, p. 319-340, 1989.

[6] Deci, E. L. Intrinsic motivation. New York: Plenum Press, 1975.

[7] Dias, Donaldo de Souza. Managers' motivation for using information technology. Industrial Management \& Data Systems, v. 98, n. 7, p. 338-342, 1998.

[8] Dias, Donaldo de Souza. Motivation for using information technology. In: Mehdi Khosrow-Pour (ed.). Managing Information Technology in a Global Economy. Idea Group Publishing, 2001.

[9] Dias, Angélica F.S.; Silva, Mônica F.; Schmitz, Eber; Dias, Donaldo de S.; Motivational measures of TAM factors: an investigation of handicapped users in Rio de Janeiro, 2005 BALAS, Madri, Espanha, 2005. 
[10] Fishbein, M.; Ajzen, I. Belief, attitude, intentions and behavior: an introduction to theory and research. Boston: Addison-Wesley, 1975.

[11] Igbaria, Magid; Parasuraman, Saroj; Baroudi, Jack J. A motivational model of microcomputer usage. Journal of Management Information Systems, v. 13, n. 1, p. 127-143, 1996.

[12] JAWS. Disponível em: <http://www.freedomscientific.com/>, acesso em 19 de julho de 2006.

[13] Malhotra, Naresh K. Pesquisa de marketing: uma orientação aplicada. 3. ed. Porto Alegre: Bookman, 2001.

[14] Mann, Peter H. Métodos de investigação sociológica. 4. ed. Rio de Janeiro: Zahar, 1979.

[15] Naumann, C. M., Souza, S. G. (2004). Proposta para Desenvolvimento de Metodologia de Ensino e de Ferramental de Acessibilidade para a Qualificação Profissional de Deficientes Visuais e Motores, XXX Conferencia Latinoamerica de Informática - CLEI 2004. Arequipa, Peru.

[16] Oliveira.R.C.S , M.W Sampaio. Entendendo a Baixa Visão, s.d.

[17] Pimentel, M. - Computador, uma voz que ajuda, "Prêmio Jovem Cientista" da Fundação Roberto Marinho, 1997a]

[18] Pimentel, M.. - DOSVOX - O que você deseja - Revista Técnica do Instituto Benjamin Constant - no. 7 - 1997b]

[19] Sassaki, R.K. - Inclusão: Construindo uma Sociedade para Todos. WVA Editora e Distribuidora Ltda, Rio de Janeiro, 1997, 174 pág.

[20] Sellitiz; Wrighstman; Cook. Coleta de dados: questionários e entrevistas. In: Métodos de pesquisa nas relações sociais. São Paulo: EPU/EDUSP, 1975.

[21] Silva, Mônica F.; Dias, Donaldo de S. Intenção de Uso de Tecnologia de Informação: um estudo sobre a influência do contexto social em uma empresa do setor acadêmico brasileiro, XXXIX CLADEA, Puerto Plata, República Dominicana, 2004.

[22] Silva, Mônica F. Fatores Humanos e sua influência na Intenção de Uso de Sistemas de Informação. Tese de Doutorado apresentada ao Programa de Pós-Graduação em Administração, Instituto COPPEAD de Administração, Universidade Federal do Rio de Janeiro. 2006.

[23] Turban, Efraim; RAINER JR., R. Kelly; POTTER, Richard E. Administração de tecnologia da informação. Rio de Janeiro: Campus, 2003.

[24] Venkatesh, V. Determinants of perceived ease of use: integrating control, intrinsic motivation, and emotion into the technology acceptance model. Information Systems Research, v.11, n.4, p.342-365, Dec. 2000.

[25] Venkatesh, V.; Davis, F.D. A Theoretical Extension of the Technology Acceptance Model: Four Longitudinal Field Studies. Management Science, v. 46, n. 2, 2000, p. 186-204.

[26] Venkatesh, V.; Morris, M. G.; Davis, G. B.; Davis, F. D. User Acceptance of Information Technology: Toward a Unified View. MIS Quarterly, v. 27, n. 3, 2003, p. 425-478.

[27] Virtual Vision - Programa leitor de telas. Desenvolvido pela MicroPower em conjunto com a Fundação Banco Bradesco. Disponível em: <http://www.micropower.com.br>, acesso em: 19 de julho de 2006. 